\title{
Soybean growth and yield after single tillage and species mixture of cover plants ${ }^{1}$
}

\author{
Gislaine Piccolo de Lima², Lúcia Helena Pereira Nóbrega³, Márcia Maria Mauli², \\ Danielle Medina Rosa ${ }^{2}$, Adriana Smanhotto
}

\begin{abstract}
The use of cover crops is important for the agricultural crop and soil management in order to improve the system and, consequently, to increase yield. Therefore, the present study analyzed the effect of crop residues of black oat (Avena strigosa Schreb.) (BO) and a cocktail (CO) of BO, forage turnip (Raphanus sativus L.) (FT) and common vetch (Vicia sativa L.) (V) on the emergence speed index (ESI), seedling emergence speed (SES) plant height and soybean yield in different intervals between cover crop desiccation with glyphosate 480 ( $3 \mathrm{~L} \mathrm{ha}^{-1}$ ) and BRS 232 cultivar sowing. Plots of $5 \times 2.5 \mathrm{~m}$ with $1 \mathrm{~m}$ of border received four treatments with BO cover crops and four with CO as well as a control for each cover crop, at random, with five replications. The plots were desiccated in intervals of 1, 10, 20 and 30 days before soybean seeding. The harvest was manual while yield was adjusted to $13 \%$ of moisture content. The experimental design was completely randomized with splitplots and means compared by the Scott and Knott test at 5\% of significance. The results showed that $\mathrm{CO}$ of cover crops can be recommended for soybean to obtain a more vigorous seedling emergence, from 10 days after cover crop desiccation.
\end{abstract}

Key words: no-tillage system, crop rotation, Glycine max (L.) Merr.

\section{RESUMO}

\section{Crescimento e produtividade de soja após cultivo solteiro e coquetel de plantas de cobertura}

A adequação da cobertura vegetal à cultura agrícola e ao manejo de solo é importante para obtenção de melhorias do sistema e, consequentemente, de maior produtividade. Nesse contexto, este estudo analisou a interferência de restos vegetais de aveia preta (Avena strigosa Schreb) (AP) e coquetel de aveia preta, nabo forrageiro (Raphanus sativus L.) e ervilhaca-comum (Vicia sativa L.) (CO) no índice de velocidade de emergência (IVE), velocidade de emergência (VE) de plântulas, altura de plantas e produtividade da cultura da soja em intervalos diferenciados entre dessecação da cobertura vegetal com glifosato 480 (3L ha-1) e semeadura da cultivar BRS 232. Parcelas de $5 \mathrm{~m}$ x 2,5 m, com $1 \mathrm{~m}$ de bordadura, receberam quatro tratamentos com cobertura AP, quatro para CO e uma testemunha para cada cobertura, ao acaso, com cinco repetições. A dessecação foi nos intervalos de 1, 10, 20 e 30 dias anteriores à semeadura da soja. A colheita foi manual e a produtividade, ajustada para $13 \%$ de teor de água. O delineamento experimental foi inteiramente casualizado, em esquema de parcelas subdivididas, teste de Scott e Knott a 5\% de probabilidade. Pelos resultados obtidos pode-se recomendar a utilização do coquetel de coberturas na cultura da soja a fim de proporcionar emergência de plântulas mais vigorosas. A semeadura da soja é recomendada a partir de 10 dias após a dessecação da cobertura vegetal.

Palavras-chave: plantio direto, rotação de cultura, Glicyne max (L.) Merr.

Received for publication on October $10^{\text {th }}, 2010$ and approved on October $04^{\text {th }}, 2012$.

1 Extracted from the Master's degree dissertation, presented by the first author at Universidade Estadual do Oeste do Paraná, with financial support by CAPES

${ }^{2}$ Biologist. Doctoral student at Universidade Estadual do Oeste do Paraná, Rua Universitária, 2069, Jardim Universitário, 85819-110, Cascavel, Paraná, Brasil. gisalipi@ yahoo.com.br; marcia.m.mauli@gmail.com; danimrosa@yahoo.com.br

${ }_{3}^{3}$ Agronomist Engineer. Universidade Estadual do Oeste do Paraná, Rua Universitária, 2069, Jardim Universitário, 85819-110, Cascavel, Paraná, Brasil. lucia.nobrega @unioeste.br (correspondent author).

${ }^{4}$ Agricultural Engineering, Doctor. Pontifícia Universidade Católica, Campus de Toledo, Av. da União, 500, Jardim Coopagro, 85902-532, Toledo, Paraná, Brasil. adriana.smanhotto@pucpr.br 


\section{INTRODUCTION}

Highest efficiency, with improvements on the productive capacity of the soil requires planning for the crops to be grown, considering speciesof high biomass production with potential for soil mulching, cultivated either in the cocktail or single form, with commercial crops (Embrapa, 2004).

The mulching process is an ecological and economic alternative for soil management, bringing balance to the chemical, physical and biological properties that compose the soil-plant system (Rufato et al., 2006). With the expansion of soybean crop, the no-tillage system and the establishment of winter crops for soil mulching are techniques that emphasize the recovery and improvement of productivity (Silva et al., 1997). However, the success of this system depends on the interval existent between the mulch desiccation and the sowing (Timossi et al., 2005).

Leaf chlorosis and decrease in plant development (which can affect productivity) have been commonly observed in areas covered with a great mass of mulches, where the seed sowing is carried in intervals very near to the desiccation (Constantin \& Oliveira, 2005). Therefore, the choice and the correct management are determinant in the formation and recovery of the mulch and the resulting benefits (Pires et al., 2008).

The fast and uniform emergence of healthy seedlings in open field is important for the establishing of uniform stands, which will provide a faster spread of mulches and, depending on the crop, higher competitiveness against weeds (Lima, 1997).

Fast emerging seedlings are able to compete more efficiently for environment resources (Fleck et al., 2002). Theoretically, strong seedlings have advantage to become a high plant (Flores et al., 2002). Stronger seeds generate seedlings with higher growth indices due to their capacity of transformation and supplying reserves in the storage tissues and the higher incorporation of tissues by the embryonic axis. The growth of seedlings can be evaluated by the measurement of the mean length of normal seedlings and it is considered that samples with higher mean values are the strongest ones (Dan et al., 1987).

Among probable effects promoted by the deposition of a straw layer, provided by the soil mulch, the allelopathy represents the influence of one individual over another (Rice, 1984). This influence can be positive or negative, through the effects of the biomolecules produced by a plant and released into the environment, either in the aqueous phase of the soil or substratum, gaseous substances released into the environment, or by decomposition and leaching. Thus, the germinating process and the development of other plant species change affecting the constitution of the natural ecosystems and crops (Perez et al., 1998). Plant wastes in the soil surface interfere with humidity, luminosity and soil temperature - the main factors in controlling dormancy and the germinating process (Correia \& Rezende, 2002).

Therefore, the aim of this study was to analyze a probable effect of plant wastes on the following mulches: black single oat and black cocktail oat, forage turnip and common vetch in initial development, growth and productivity of soybean crop, considering different intervals between the mulch desiccation and the crop sowing.

\section{MATERIAL AND METHODS}

\section{Description of the experimental area}

The experiment was set in the agricultural year of 2006/ 07, in Braganey, in western Paraná, with the geographical coordinates $24^{\circ} 54^{\prime} 08^{\prime \prime} \mathrm{S}$ of latitude and $53^{\circ} 07^{\prime} 15^{\prime \prime} \mathrm{W}$ of longitude, at $643 \mathrm{~m}$. The experimental area had a 4-year history of no-tillage system, with soybean and corn in the summer, and black oat in the winter. The soil is classified as an eutrophic Red Latosol, with an annual rainfall average of $1.600 \mathrm{~mm}$, and an annual average temperature of $20^{\circ} \mathrm{C}$ (Caviglione et al., 2000).

\section{Pre-sowing management and crop management}

Soil preparation, implantation of mulches and the crop, all occurred under the no-tillage system. Initially, a desiccation of plant wastes in the area was carried out using the herbicide 480 glyphosphate $\left(1.44 \mathrm{~L} \mathrm{ha}^{-1}\right.$ of the active ingredient, $3 \mathrm{~L} \mathrm{ha}^{-1}$ of commercial product). Twenty days after the desiccation, the vegetal mulches were sown (08/12/2006), namely: black oat $\left(50 \mathrm{~kg} \mathrm{ha}^{-1}\right)$ in a single system, and black oat (30 kg ha-1), forage turnip $\left(8 \mathrm{~kg} \mathrm{ha}^{-1}\right)$ and common vetch $\left(15 \mathrm{~kg} \mathrm{ha}^{-1}\right)$ as cocktail, with a $0.15 \mathrm{~m}$ spacing between lines, a control without mulching, only with the spontaneous species (fallow).

The desiccation of the plots with mulches was also carried out with 480 glyphosphate (1.44 $\mathrm{L} \mathrm{ha}^{-1}$ of the active ingredient) in intervals of one, ten, twenty and thirty days, before the soybean sowing (11/15/2006). Next, plots of $5 \mathrm{x}$ $2.5 \mathrm{~m}$, with a $1 \mathrm{~m}$ border between them and thirteen sowing lines were all lined off, with a $0.45 \mathrm{~m}$ spacing among them and 14 soybean seeds per meter. The plot useful area was $12.5 \mathrm{~m}^{2}$, and eight sowing lines were used for the evaluation.

The sowing was carried out with a Metasa planter, in the time recommended for the region. A 2-20-20NPK formulation was applied in the furrow at the rate of $300 \mathrm{~kg}$ $\mathrm{ha}^{-1}$, as recommended by the soil analysis. The semiprecocious cultivar BRS 232, indicated for the State of Paraná (Embrapa, 2006), and previously subjected to a 
germination test in laboratory, resulting in a $90 \%$ rate of germination was used in the experiment. Four treatments were established for the black oat mulch in single system, and four treatments for the cocktail with one control for each cover, randomly distributed, with five replications per treatment.

\section{Evaluations}

After sowing of the soybean crop, the emergence velocity index (EVI), emergence velocity (ES), plant height and yield were evaluated, as follows:

ESI: count of emerged plants in the useful lines of each plot, according to the agronomical criteria of emergence, that is, the presence of essential structures so the seedling is able to continue development (Brasil, 2009). The evaluation started from the fourth day up to the stabilization of the number of emerged seedlings, which happened around 20 days (Nakagawa, 1999).

$$
E S I=\frac{E_{1}}{N_{1}}+\frac{E_{2}}{N_{2}}+\ldots+\frac{E_{N}}{N_{N}}
$$

Where:

$\mathbf{E S I}=$ emergence speed index.

$\mathrm{E}_{1} \mathrm{E}_{2} \ldots \mathrm{E}_{\mathrm{N}}=$ number of normal seedlings recorded in the first, second, (...) up to the last count.

$\mathrm{N}_{1}, \mathrm{~N}_{2} \ldots \mathrm{N}_{\mathrm{N}}=$ number of sowing days up to the first, the second, (...) up to the last count.

ES: data used to evaluate the ES were the same used in the ESI evaluation. ES was calculated according to Edmond \& Drapala (1958), considering the treatment with the lowest mean the one that took fewer days for the emergence of seedlings from the soil, therefore considered the one with the highest ES:

$$
E S=\frac{\left(N_{1} E_{1}\right)+\left(N_{2} E_{2}\right)+\ldots\left(N_{n} E_{n}\right)}{E_{1}+E_{2}+\ldots E_{n}}
$$

Where:

$\mathrm{ES}=$ emergence velocity.

$\mathrm{E}_{1}, \mathrm{E}_{2} \ldots \mathrm{E}_{\mathrm{N}}=$ number of normal seedlings recorded in the first, second, (...) up to the last count.

$\mathrm{N}_{1}, \mathrm{~N}_{2} \ldots \mathrm{N}_{\mathrm{N}}=$ number of sowing days up to the first, the second, (...), up to the last count.

The results were expressed in the number of days that the seedlings took to emerge from the soil.

Plant height: the aerial part was measured considering the distance from the soil up to the apical meristem in the main stem, of ten soybean seedlings, randomly chosen within the useful area of each plot, for each treatment and the control. The evaluations were carried out at monthly intervals, starting from 30 days after the sowing. The results were expressed in $\mathrm{cm}$.
Yield: a manual harvest of each plot was carried out after maturation, by pulling the plants off the useful lines. Plants were spread on a canvas and hit with a stick to release the seeds and were cleaned by manual waving in sieves. The selected seeds were packed, identified and taken to the laboratory so that the yield could be determined by weighing the seeds of each plot and transformed into $\mathrm{kg} \mathrm{ha}^{-1}$. Then, all the values were adjusted for $13 \%$ water content.

\section{Experimental design}

The experiment was arranged in a completely randomized design, using a split-plot in time and four treatments for the black oat, four treatments for cocktail and a single control for each mulch, with five replications for each treatment. The main factors - the mulches (vegetal cover) - were placed in the plots. They were, then, divided in subplots, in which the secondary factors were distributed, that is, the intervals between desiccation (1, 10, 20 and 30 days) and sowing (Banzatto \& Kronka, 1992).

Data on yield did not show normality and were transformed into $\sqrt{x}$ (Banzatto \& Kronka, 1992). The results were subjected to a analysis of variance, and the means were compared by the Scot-Knott test at $5 \%$ probability. The classification of the values for the coefficient of variation (CV) was according to Pimentel Gomes (2000).

\section{RESULTS AND DISCUSSION}

The highest emergence speed index (ESI) was recorded for the treatment with the mulch cocktail, indicating that it was beneficial to the ESI of the soybean crop (Table 1).

For the intervals between desiccation and sowing (IDS), the highest ESIs were at 10, 20 and 30 days after the desiccation, differing from the control and from the day 1 IDS, which had the lowest ESI, also differing from the control. Laboratory-based studies performed by Nóbrega et al. (2009), showed a negative influence of ryegrass, black oat and black oat cocktail, common vetch and forage turnip mulching on the emergence and ESI percentage of soybean seedlings. However, the authors did not found significant difference between the single mulches and the cocktail.

The results for ES (Table 2) showed a behavior similar to those obtained for the ESI. The soybean sowed on day 1 after the desiccation demanded a higher amount of days for emergence. That may due to the higher concentration of constitutive substances of the cover crops with allelopathic potential, without discarding, though, the possibility of the residual effect of the herbicide used. Days 10, 20 and 30 IDSs

Rev. Ceres, Viçosa, v. 59, n.5, p. 695-700, set/out, 2012 
presented a lower amount of days to the soybean mean seedling emergence when compared with the control and with the day 1 IDS, which also differed between each other (Table 2).

The lower the values obtained by the ES formula are, the higher the seed physiological potential (Edmond \& Drapala, 1958). That result allowed the inference that Days 10, 20 and 30 IDSs favored seed germination when compared with the control and to the day 1 IDS, which differed from each other. These data confirmed the results obtained by the ESI test (Table 1).

Bortolini \& Fortes (2005) reported a decrease in the ES of soybean seeds exposed to the black oat aqueous extract, in laboratory-based experiments. Similar results were observed in this study, in which there was an alteration in the ES of the soybean seedlings subjected to black oat and black oat cocktail, common vetch and forage turnip mulching with day 1 IDS.

Timossi et al. (2005) reported an increase in the average amount of days to the soybean seedlings emergence, when the mulching desiccation was performed at seven and zero days before the crop sowing; thus, corroborating the findings of the present study.

Table 3 shows that at 30 and 60 days after the sowing (DAS), the day 1 IDS differed from the control and from the other treatments, with lower plant height. At 90 DAS, it was observed higher values for plant height in the 20 and 30 days IDSs. At 120 DAS, the day 30 IDS had higher plant height and was not statistically different from days 10 and 20 IDSs (Table 3).

Table 1. Unfolding of means of the mulching parameters and interval between desiccation and sowing (IDS) for the emergence speed index (ESI) of soybean seedlings

\begin{tabular}{lccc}
\hline Mulch & ESI & IDS & ESI \\
\hline Black Oat & $2.56 \mathrm{a}$ & control & $2,52 \mathrm{~b}$ \\
Cocktail & $2.64 \mathrm{~b}$ & 1 day & $1.98 \mathrm{a}$ \\
& & 10 days & $2.87 \mathrm{c}$ \\
& & 20 days & $2.74 \mathrm{c}$ \\
& & 30 days & $2.89 \mathrm{c}$ \\
\hline
\end{tabular}

Means followed by the same letter, in the column, are not significantly different by the Scott-Knott test at $5 \%$ probability.

Table 2. Means of the intervals between desiccation and sowing (IDS) for emergence velocity (ES) of soybean seedlings cultivated under mulching

\begin{tabular}{lc}
\hline IDS & ES (Average days to emergence) \\
\hline Control & $10.5 \mathrm{~b}$ \\
1 day & $11.8 \mathrm{c}$ \\
10 days & $9.3 \mathrm{a}$ \\
20 days & $9.7 \mathrm{a}$ \\
30 days & $9.7 \mathrm{a}$ \\
\hline
\end{tabular}

Means followed by the same letter, in the column, are not significantly different by the Scott-Knott test at $5 \%$ probability.
According to Merotto Júnior et al. (1999), the plants with late emergence can have lower growth in the aerial part and in the root system, and, as a result, a lower capacity of quantitative competition for water, light and nutrients.

Souza Filho \& Alves (2002) discussed that the plant height is one of the criteria usually evaluated in the determination of the presence of an allelopathic agent. These authors, by quoting Williamson \& Weidenhamer (1990), emphasized that a little flow of allelochemicals in the soil may interfere in plant height. Menezes et al. (1994) observed allelopathic substances in black oat exudations, which were capable of inhibiting the development of crops; they suggested a longer interval between the desiccation and sowing management, in order to decrease the depressive allelopathic effects.

From the first (30 DAS) to the last evaluation (120 DAS), the mulches, after the 10 days IDS, provided a greater plant height in relation to the control. That may have occurred due to the protection of the soil, provided by the mulches, or yet, by the supply of organic matter.

The results observed agree with those reported by Constantin \& Oliveira (2005), who emphasized the attention with the interval between the mulching desiccation and the crop sowing. Findings from areas with a great mulching mass, with sowing performed a few days after the desiccation, show a decrease in the plant development, which may affect the productivity. Rice (1984) discussed that the allelopathic effects detected on the growth of a plant, by an allelochemical originated from crop residues, depend, among other factors, on the residue age, that is, on the stage of decomposition in which the plant that donated the residues was.

According to Silva et al. (2006), plant height is the parameter that determines the degree of development of the crop and has a positive correlation with yield, which may demonstrate that they are more productive, probably because they are under less stress during their development and accumulate higher amounts of reserves.

Table 3. Unfolding of means of the intervals between desiccation and sowing (IDS) for soybean plant height (cm) evaluated at 30 , 60, 90 and 120 days after sowing (DAS)

\begin{tabular}{lcccc}
\hline \multirow{2}{*}{ IDS } & \multicolumn{4}{c}{ DAS } \\
\cline { 2 - 5 } & $\mathbf{3 0}$ & $\mathbf{6 0}$ & $\mathbf{9 0}$ & $\mathbf{1 2 0}$ \\
\hline Witness & $17.3 \mathrm{~b}$ & $73.9 \mathrm{~b}$ & $75.7 \mathrm{a}$ & $75.0 \mathrm{a}$ \\
1 day & $15.3 \mathrm{a}$ & $69.7 \mathrm{a}$ & $76.7 \mathrm{a}$ & $73.6 \mathrm{a}$ \\
10 days & $18.3 \mathrm{~b}$ & $75.1 \mathrm{~b}$ & $76.8 \mathrm{a}$ & $76.2 \mathrm{~b}$ \\
20 days & $18.4 \mathrm{~b}$ & $75.9 \mathrm{~b}$ & $79.9 \mathrm{~b}$ & $76.7 \mathrm{~b}$ \\
30 days & $18.4 \mathrm{~b}$ & $75.4 \mathrm{~b}$ & $78.8 \mathrm{~b}$ & $78.6 \mathrm{~b}$ \\
\hline
\end{tabular}

Means followed by the same letter, in the column, are not significantly different by the Scott-Knott test at $5 \%$ probability.

Rev. Ceres, Viçosa, v. 59, n.5, p. 695-700, set/out, 2012 
Yield means did not differ between the black oat and cocktail mulches. The mean IDS shows a lower productivity for the soybean sowed 1 day after the cocktail desiccation handling (Table 4).

In the unfolding of means for IDS, in the black oat mulching, showed lower productivities in days 1 and 30 IDS, which differed from the control and from the other treatments. Day 10 IDS had the highest yield (Table 4).

In a similar study, Neves et al. (1999) did not observe any variation in the corn yield for days 1 and 13 IDS using black oat mulching. However, Constantin et al. (2009) reported results that resembled those found in this study, with a decrease in the soybean yield under the BO burn down system and single desiccation seven days before the sowing when compared to the sequential management system.

The unfolding of means for IDS, in the cocktail, there was a higher yield in the con trol and in the day 30 IDS; the day 1 IDS showed lower yield and was not statistically different from days 10 and 20 IDS, indicating that these mulches, after a few days of desiccation, interfere with the soybean crop yield.

Nevertheless, Rizzardi et al. (2003) reported a reduction in the soybean yield for the day 30 IDS due to the interference of weed species that begin to compete with the crop.

Comparing the yields of $3.030 \mathrm{~kg} \mathrm{ha}^{-1}$ for the soybean crop in Paraná (IBGE, 2008) and of $2.755 \mathrm{~kg} \mathrm{ha}^{-1}$ for Brazil (CEPEA, 2008), with the ones obtained in this work, it is found that the yield data gathered in this study is within the standards considered normal for the region.

One can observe that the average results for productivity presented the same behavior as the results obtained for ESI, ES and plant height. Higher productivities were verified from the 10 days IDS, what was also verified for the other parameters analyzed.

Table 4. Unfolding of means of the parameters mulching and interval between desiccation and sowing (IDS) for the soybean yield $\left(\mathrm{kg} \mathrm{ha}^{-1}\right)$ obtained from cover crops and intervals differentiated between desiccation and sowing (IDS)

\begin{tabular}{lccc}
\hline \multirow{2}{*}{ IDS } & \multicolumn{3}{c}{ Mulching } \\
\cline { 2 - 4 } & Black Oat & Cocktail & Means \\
\hline Witness & $3062 \mathrm{Ab}$ & $3062 \mathrm{Ab}$ & $3062 \mathrm{~b}$ \\
1 day & $2686 \mathrm{Aa}$ & $2618 \mathrm{Aa}$ & $2652 \mathrm{a}$ \\
10 days & $3102 \mathrm{Bb}$ & $2646 \mathrm{Aa}$ & $2874 \mathrm{~b}$ \\
20 days & $3079 \mathrm{Ab}$ & $2731 \mathrm{Aa}$ & $2905 \mathrm{~b}$ \\
30 days & $2828 \mathrm{Aa}$ & $2980 \mathrm{Ab}$ & $2904 \mathrm{~b}$ \\
Averages & $2951 \mathrm{~A}$ & $2808 \mathrm{~A}$ & \\
\hline
\end{tabular}

Means followed by the same small letter in the column and capital letters in the row are not significantly different by the Scott-Knott test at $5 \%$ probability. The presented data are obtained from the original observations, followed by the letters from the comparison of means transformed into $\sqrt{\mathrm{x}}$.

\section{CONCLUSIONS}

The emergence speed index (ESI) for the soybean culture was benefited from the mulching cocktail, providing the emergence of vigorous seedlings.

The sowing of soybean is recommended ten days after mulching desiccation (10 days IDS), enabling the achievement of vigorous plants of greater size.

Sowing soon after the mulching desiccation (one day interval between desiccation and sowing) interferes negatively in the ESI, ES, plant height and the soybean yield.

\section{REFERENCES}

Banzatto DA \& Kronka SN (1992) Experimentação agrícola. Jaboticabal, FUNEP. 247p

Bortolini MF \& Fortes MT (2005) Efeitos alelopáticos sobre a germinação de sementes de soja (Glycine max (L.) Merrill). Semina: Ciências Agrárias, 26:05-10.

Brasil (2009) Regras para análise de sementes. Brasília, Ministério da Agricultura e Reforma Agrária. 365p.

Caviglione JH, Kiihl LRB, Caramori PH \& Oliveira D (2000) Cartas climáticas do Paraná, Londrina. Anais, IAPAR. CDROM.

CEPEA - Centro de Pesquisas Econômicas da Escola Superior de Agricultura Luiz de Queiroz (2008) Soja: Clima favorece produtividade. Disponível em: <http://www.sindrural.com.br/content/ view/760/140/>. Acessado em: 22 de janeiro de 2008.

Constantin J, Oliveira RS, Zobiole LHS, Dalbosco M, Arantes JG \& Alonso DG (2009) Influência de sistemas de manejo sobre o desenvolvimento e a produtividade da soja. Revista Ceres, 56:274-282

Constantin J \& Oliveira RS (2005) Dessecação antecedendo a semeadura direta pode afetar a produtividade. Informações Agronômicas, 109:14-15.

Correia NM \& Rezende PM (2002) Manejo integrado de plantas daninhas na cultura da soja. Lavras, Editora UFLA. 55p. (Boletim Agropecuário, 51).

Dan EL, Mello VDC, Wetzel CT, Popinigis F \& Souza EP (1987) Transferência de matéria seca como método de avaliação do vigor de sementes de soja. Revista Brasileira de Sementes, 9:45-55.

Edmond JB \& Drapala WJ (1958) The effects of temperature, sand and soil, and acetone on germination of okra seeds. Proceedings of American Society of Horticultural Science, $71: 428-434$

Embrapa - Empresa Brasileira de Pesquisa Agropecuária (2006) Embrapa soja. Cultivares. Disponível em: <www.cnpso.embrapa.br/index.php?op_page=299\&cod_pai=171 - 30k>. Acessado em: 26 de maio de 2006.

Embrapa - Empresa Brasileira de Pesquisa Agropecuária (2004) Tecnologias de produção de soja Paraná 2004. Rotação de culturas. Disponível em: <http://www.cnpso.embrapa.br/ producaosojaPR/rotacao.htm>. Acessado em: 10 de outubro de 2006.

Fleck NG, Rizzardi MA, Vidal RA, Meroto Júnior A, Agostinetto D \& Balbinot Júnior AA (2002) Período crítico para controle de Brachiaria plantaginea em função de épocas de semeadura da soja após dessecação da cobertura vegetal. Planta Daninha, 20:53-62.

Rev. Ceres, Viçosa, v. 59, n.5, p. 695-700, set/out, 2012 
Flores IF, Passamani S, Bonow RN \& Lemos CA (2002) Tratamento de sementes com ácido giberélico e crescimento de plântulas de arroz (Oryza sativa L.). Revista da Faculdade de Zootecnia, Veterinária e Agronomia, 9:73-78.

IBGE - Instituto Brasileiro de Geografia e Estatística (2008) IBGE revela que o Paraná é campeão nacional na produtividade de soja e milho. Disponível em: <http://www.aenoticias.pr.gov.br/ modules/news/article.php?storyid=34309>. Acessado em: $22 \mathrm{de}$ janeiro de 2008.

Lima RM (1997) Efeito do tamanho das sementes sobre alguns atributos fisiológicos e agronômicos. Associação brasileira dos produtores de sementes, Anuário ABRASEM. p.39-43.

Menezes VG, Andreis A, Souza PR \& Carrão VH (1994) Serradela nativa: Uma alternativa de inverno para as várzeas do sul do Brasil. Lavoura Arrozeira, 47:19-22.

Merotto Júnior A, Sangoi L, Ender M, Guidolin AF \& Haverroth HS (1999) A desuniformidade de emergência reduz o rendimento de grãos de milho. Ciência Rural, 29:595-601.

Nakagawa J (1999) Testes de vigor baseados no desempenho de plântulas. In: Krzyzanowski FC, Vieira RD \& França Neto JB (Eds.) Vigor de sementes: Conceitos e testes. Londrina, Abrates. p.01-24.

Neves R, Fleck NG \& Vidal RA (1999) Intervalo de tempo para semeadura de milho pós-dessecação da cobertura de aveia-preta com herbicidas. Ciência Rural, 29:606-608.

Nóbrega LHP, Piccolo de Lima G, Martins GI \& Meneghetti AM (2009) Germinação de sementes e crescimento de plântulas de soja (Glycine max L. Merrill) sob cobertura vegetal. Acta Scientiarum Agronomy, 31:461-465.

Perez MTLP, Pizzolatti MG, Queiroz MH \& Yunes RA (1998) Potencial de atividade alelopática de Gleichenia pectinada Willd (Pr). Pesquisa Agropecuária Brasileira, 33:131-137.
Pimentel Gomes F (2000) Curso de estatística experimental. 14 ${ }^{\mathrm{a}}$ ed. Piracicaba, Nobel. 477p.

Pires FR, Assis RL, Procópio SO, Silva GP, Moraes LL, Rudovalho MC \& Bôer CA (2008) Manejo de plantas de cobertura antecessoras à cultura da soja em plantio direto. Revista Ceres, 55:94-101.

Rice EL (1984) Allelopathy. $2^{\text {a }}$ ed. New York, Academic Press. $422 \mathrm{p}$.

Rizzardi MA, Fleck NG, Agostinetto D \& Balbinot Jr AA (2003) Previsão da perda de rendimento de grãos de soja causada pela infestação de plantas daninhas utilizando variáveis foliares relativas. Planta Daninha, 21:45-54.

Rufato L, Rossi A, Picolotto L \& Fachinello JC (2006) Plantas de cobertura de solo em pomar de pessegueiro conduzido no sistema de produção integrada. Revista Ciência Rural, 36:814-821.

Silva DA, Vitorino ACT, Souza LCF, Gonçalves MC \& Roscoe R (2006) Culturas antecessoras e adubação nitrogenada na cultura do milho, em sistema plantio direto. Revista Brasileira de Milho e Sorgo, 5:75-88.

Silva PRF, Wendt W \& Rocha AB (1997) Manejo do solo e adubação na cultura do girassol em sucessão a aveia preta. Pesquisa Agropecuária Brasileira, 32:641-647.

Souza Filho APS \& Alves SM (2002) Alelopatia: Princípios básicos e aspectos gerais. Belém, Embrapa Amazônia Oriental. 260p.

Timossi PC, Leite GJ \& Durigan JC (2005) Influência das épocas de manejo de milheto na emergência de plântulas de soja. Jaboticabal, SBCPD. p.5-10. (Boletim informativo, 3).

Williamson, GB \& Weidenhamer JD (1990) Bacterial degradation of juglone: Evidence against allelopathy. Journal of Chemical Ecology, 16:1739-1742. 